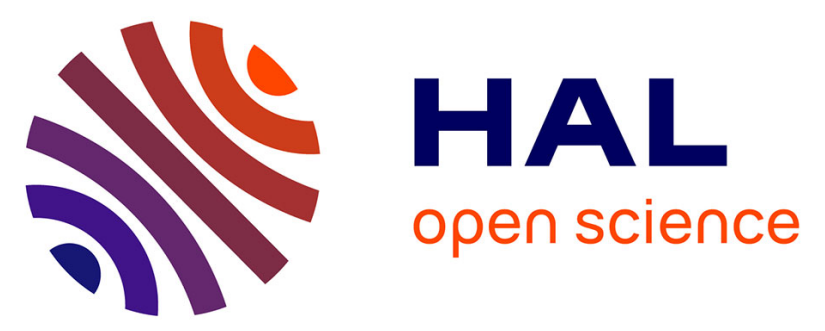

\title{
Minor and trace-elements in apiary products from a historical mining district (Les Malines, France)
}

\author{
Guillaume Losfeld, Jean-Baptiste Saunier, Claude Grison
}

\section{To cite this version:}

Guillaume Losfeld, Jean-Baptiste Saunier, Claude Grison. Minor and trace-elements in apiary products from a historical mining district (Les Malines, France). Food Chemistry, 2014, 146, pp.455-459. 10.1016/j.foodchem.2013.08.105 . hal-03172545

\section{HAL Id: hal-03172545 \\ https://hal.science/hal-03172545}

Submitted on 17 Mar 2021

HAL is a multi-disciplinary open access archive for the deposit and dissemination of scientific research documents, whether they are published or not. The documents may come from teaching and research institutions in France or abroad, or from public or private research centers.
L'archive ouverte pluridisciplinaire HAL, est destinée au dépôt et à la diffusion de documents scientifiques de niveau recherche, publiés ou non, émanant des établissements d'enseignement et de recherche français ou étrangers, des laboratoires publics ou privés. 


\title{
Minor and trace-elements in apiary products from a historical mining district (Les Malines, France)
}

\author{
Guillaume Losfeld ${ }^{\mathrm{a}}$, Jean-Baptiste Saunier ${ }^{\mathrm{a}}$, Claude Grison ${ }^{\mathrm{a}, *}$ \\ ${ }^{a}$ Centre d'Ecologie Fonctionnelle et Evolutive, UMR 5175 CNRS, 1919 Route de Mende, F34293 Montpellier, France
}

\begin{abstract}
A B S T R A C T
The trace-elements (TE) contents of honey, royal-jelly and beeswax from a historical $\mathrm{Zn}-\mathrm{Pb}$ mining district have been investigated to assess potential contamination. In spite of high levels of heavy metal (As, $\mathrm{Cd}, \mathrm{Tl}, \mathrm{Pb}$ ) in wastes left after mining stopped, apiary products appear to be relatively free of TE contamination. For honey, the following average levels ( \pm standard error) were observed: $\mathrm{Zn} 571 \pm 440 \mu \mathrm{g} \mathrm{kg}^{-1}$, $\mathrm{Pb} 26 \pm 20 \mu \mathrm{g} \mathrm{kg}-1$, Tl $13 \pm 10 \mu \mathrm{g} \mathrm{kg}^{-1}, \mathrm{Cd} 7 \pm 6 \mu \mathrm{g} \mathrm{kg}-1$ and As $3 \pm 4 \mu \mathrm{g}^{-\mathrm{kg}^{-1}}$. These results bring additional data to the potential impact of brownfields left after mining on apiary products. They also bring new data to assess potential risks linked with honey consumption and discuss legal TE contents in honey and other food products from apiaries.
\end{abstract}

Keywords:

Honey

Apiary products

Trace elements

Historical mining

Guide values

\section{Introduction}

With regards to TE in honey and apiary products, various studies have been undertaken with different aims. Some focus on the use of TE to certify geographical origins (Hernandez, Fraga, Jimenez, Jimenez, \& Arias, 2005; Terrab, Gonzalez, Diez, \& Heredia, 2003; Terrab, Recamales, Gonzalez-Miret, \& Heredia, 2005) or to assess quality (Devillers et al., 2002; Pisani, Protano, \& Riccobono, 2008). The use of apiary products for TE biomonitoring has also been extensively investigated (Bilandzic et al., 2011; Lambert et al., 2012; Tuzen, Silici, Mendil, \& Soylak, 2007) and reviewed (Bogdanov, 2006; Pohl, Sergiel, \& Stecka, 2009).

Contradictory conclusions were found with regards to the use of apiary products for TE environmental monitoring. Tuzen et al. (2007) suggested the use of honey, while according to Bogdanov, Haldimann, Luginbuhl, and Gallmann (2007), low TE concentrations and high natural variations should deter from using honey. In the case of $\mathrm{Pb}$ recent studies also showed that honey was the least affected matrix from beehives, but could nonetheless be used for environmental monitoring (Lambert, et al., 2012; Mihaly Cozmuta, Bretan, Mihaly Cozmuta, Nicula, \& Peter, 2012). In spite of abundant data from the literature, reference levels for noxious TE in honey are difficult to find (Devillers et al., 2002), and additional data on the potential impacts of a heavily contaminated environ-

\footnotetext{
* Corresponding author. Address: Claude GRISON, Centre d'Ecologie Fonctionnelle et Evolutive, UMR 5175 CNRS, 1919 Route de Mende, F34293 Montpellier, France. Tel.:+33 467613316 .

E-mail address: claude.grison@cefe.cnrs.fr (C. Grison).
}

ment on honey could improve insights and provide additional material to assess the potential risks. The present investigation of the TE content of apiary products from a historical $\mathrm{Zn}-\mathrm{Pb}$ mining district (Les Malines, southern France) aims to address these topics.

The study area, located in southern France (Fig. 1) displays drastic contrasts in its landscape. It includes a national park (Parc National des Cévennes, established 1970) and a Special Area of Conservation (SAC) of the Natura 2000 network (European Union wide network of nature protection established under the 1992 Habitats Directive), where population density is low $(<50$ people per $\mathrm{km}^{2}$ ). Most of the land outside villages is covered by holm oak (Quercus ilex) forests and chestnut (Castanea sativa) coppices (Gondard, Romane, Grandjanny, Li, \& Aronson, 2001). Thus we could expect apiary products from the area to show background TE levels.

Yet the region also has a mining history: Les Malines, where an estimated $1 \mathrm{Mt}$. ore was extracted from 1885 to 1991 remains the largest $\mathrm{Zn}-\mathrm{Pb}$ mine ever exploited in France (Leguen, Orgeval, \& Lancelot, 1991). Former mines were listed from national surveys (BRGM., 2012) and confronted with local knowledge. Locations where soil and apiary products were collected are indicated on Fig. 1.

Previous studies on the les Malines mining district reported high TE levels in soil and the occurrence of several metal hyperaccumulator plant species (Escarre et al., 2011; Grison et al., 2010). High TE levels in fish have been reported in a similar context elsewhere in the region (Monna et al., 2011), but to date no studies have been conducted on apiary products in the area. As positive relationships regarding $\mathrm{Pb}$ traceability were validated along the soil-melliferous 


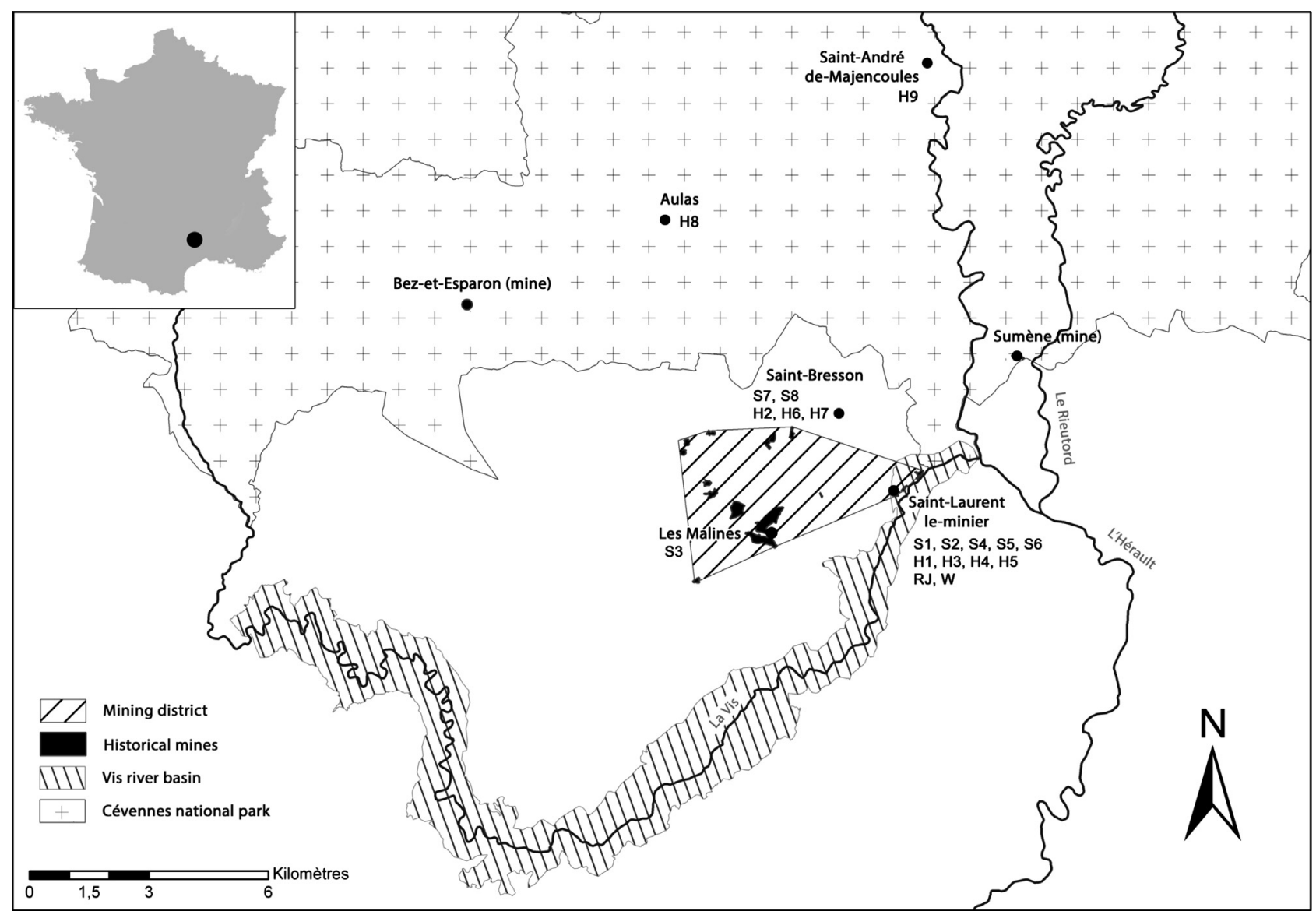

Fig. 1. Location of historical mines and sampling sites (sample names in accord with Table 2 and 3).

flora-honeybees-honey chain (Mihaly Cozmuta et al., 2012), such a study was necessary to assess honey quality from a heavily contaminated area.

\section{Methods and materials}

\subsection{General}

All reagents used in this study were of high purity grades: commercial $\mathrm{HNO}_{3}, \mathrm{HCl}$ and $\mathrm{H}_{2} \mathrm{O}_{2}$ were obtained from the Sigma-Aldrich TraceSELECT ${ }^{\circledR}$ range. All solutions were prepared using double deionised water (Milli-Q Millipore $18.2 \mathrm{M} \Omega \mathrm{cm}$ at $21^{\circ} \mathrm{C}$ ).

WEPAL IPE 110 and house standards were used as reference materials for apiary products analyses. BIPEA soil sample 402 (inter laboratory certification) was used as a reference material for soil analyses. For each digestion procedure, blank and standard digestions were carried out the same way and analysed for controls. ICP-MS analyses were performed with a Thermo scientific X Series II ICP-MS (Plateforme AETE - Hydrosciences, Montpellier - France) using In and $\mathrm{Bi}$ as internal standards.

\subsection{Apiary products}

Collection of apiary products was performed by beekeepers according to their usual harvest plans. Chestnut honey is collected from June to July. Four apiaries located in Saint-Laurent-le-Minier (les Avinières), Saint-Bresson, Aulas and Majencoules were sampled as stated in Table 3. Honey samples were obtained in generic glass jars used by beekeepers for honey retail, so as to assess the ele- mental content of honey as sold to potential consumers. Each jar contained $500 \mathrm{~g}$ honey, which allowed for measurement replicates and quality control using the standard addition method. Royal jelly and beeswax were taken directly from the hives and stored in clean polyethylene jars. An open vessel wet-digestion protocol adapted from Tuzen et al. (2007), proved efficient to recover on average $93 \%$ of the TE from apiary products. Samples were warmed to $30{ }^{\circ} \mathrm{C}$ and homogenised before $3 \mathrm{~g}$ samples were taken for analysis. $12 \mathrm{ml}$ of an oxi-acidic mixture $\left(2: 1 \mathrm{HNO}_{3}: \mathrm{H}_{2} \mathrm{O}_{2}\right)$ were added per gram sample and the resulting solution was heated at $100{ }^{\circ} \mathrm{C}$ until dry $(6 \mathrm{~h})$. Dry residues were solubilised in $\mathrm{HNO}_{3}(2.5 \% \mathrm{v}: \mathrm{v})$ for analysis.

\subsection{Soil}

Samples were taken from horizon A (Table 3). S1-S3 are not actually soil but mining waste and tailings; S4, S6 and S7 are a mixture of mineral soil and humus found around beehives (S4, S7) and pastoral areas in Saint-Laurent-le-Minier (S6); S5 and S8 are a mixture of mineral soil and waste expelled from beehives by bees. Soil samples were treated according to a house procedure: dried at $60{ }^{\circ} \mathrm{C}$ until the weight was stable, sieved to $2 \mathrm{~mm}$ and approximately $120 \mathrm{mg}$ were treated with (i) $4 \mathrm{ml} \mathrm{H} \mathrm{O}_{2}$ (ii) $4 \mathrm{ml} \mathrm{HNO}_{3}$

Table 1

French guide values for soils TE content ('sensitive use' $\mathrm{mg} \mathrm{kg}^{-1}$ dry weight).

\begin{tabular}{llllll}
\hline Element & $\mathrm{Zn}$ & As & $\mathrm{Cd}$ & $\mathrm{Tl}$ & $\mathrm{Pb}$ \\
\hline FIVs & 9000 & 37 & 20 & 10 & 400 \\
\hline
\end{tabular}


Table 2

Soil elemental contents ( $\mathrm{mg} \mathrm{kg}^{-1}$ dry weight).

\begin{tabular}{|c|c|c|c|c|c|c|c|c|c|c|c|}
\hline Sample & Type & Location & Distance from mine $^{\mathrm{a}}(\mathrm{m})$ & $\mathrm{Cr}$ & Mn & $\mathrm{Cu}$ & $\mathrm{Zn}$ & As & $\mathrm{Cd}$ & $\mathrm{Tl}$ & $\mathrm{Pb}$ \\
\hline S1 & Mine spoils & Les Avinières & 0 & 13 & 248 & 11.2 & $86706^{*}$ & $4247^{*}$ & $408^{*}$ & $317^{*}$ & 66388 \\
\hline S2 & Mine tailings & Les Avinières & 0 & na & 559 & 981 & $125456^{*}$ & $734^{*}$ & $1605^{*}$ & $37.1^{*}$ & 88472 \\
\hline S3 & Mine tailings & Les Malines & 0 & na & 1310 & 929 & $56999^{*}$ & $103^{*}$ & $386^{*}$ & 6.45 & $3686^{*}$ \\
\hline S4 & Soil around beehives & Les Avinières & 250 & 37.2 & 1131 & 29 & 3684 & $147^{*}$ & 8.79 & $16.1^{*}$ & $1234^{*}$ \\
\hline S5 & Soil under beehives & Les Avinières & 250 & 29.9 & 745 & 21.2 & 2513 & $125^{*}$ & 7.47 & 9.5 & $858^{*}$ \\
\hline S6 & Soil & St-Laurent & 500 & 37.3 & 696 & 89.1 & 2879 & $75^{*}$ & 8.26 & 3.6 & $1787^{*}$ \\
\hline S7 & Soil around beehives & St-Bresson & 1500 & 19.4 & 3767 & 30.8 & 50.8 & $159^{*}$ & $<\mathrm{dl}$ & 4.8 & 379 \\
\hline S8 & Soil under beehives & St-Bresson & 1500 & 12.3 & 1842 & 48.3 & 202 & $127^{*}$ & $<\mathrm{dl}$ & 2.6 & 369 \\
\hline
\end{tabular}

$<\mathrm{dl}=$ value below detection limit.

a Distance from the closest mine, which is les Avinières for samples collected in Saint-Laurent-le-Minier and Font-Bouillens for samples collected in Saint-Bresson.

* Values above FIVs; na = not available.

Table 3

Apiary products elemental contents ( $\mathrm{mg} \mathrm{kg}^{-1}$ or $\mu \mathrm{g} \mathrm{kg}^{-1}$ fresh weight)

\begin{tabular}{|c|c|c|c|c|c|c|c|c|c|c|c|c|}
\hline Sample & Location & Distance from mine $(\mathrm{m})$ & Season & $\mathrm{Mg}$ & $\mathrm{P}$ & $\mathrm{Ca}$ & Mn & $\mathrm{Zn}$ & As & $\mathrm{Cd}$ & $\mathrm{Tl}$ & $\mathrm{Pb}$ \\
\hline $\mathrm{H} 1$ & les Avinières & 250 & 04.2011 & 80.5 & 40.7 & 187 & 5.81 & 0.806 & 1 & 9 & 6 & 3 \\
\hline $\mathrm{H} 2$ & St-Bresson & 1500 & 05.2011 & 122 & 78.4 & 204 & 9.17 & 0.556 & 1 & 4 & 1 & 35 \\
\hline $\mathrm{H} 3$ & les Avinières & 250 & 05.2011 & 125 & 115 & 219 & 6.77 & 1.4 & 3 & 22 & 37 & 101 \\
\hline $\mathrm{H} 4$ & les Avinières & 250 & 06.2011 & 44.8 & 65.6 & 76.7 & 3.22 & 0.905 & 1 & 3 & 6 & 11 \\
\hline H5 & les Avinières & 250 & 07.2011 & 163 & 66.6 & 277 & 10.5 & 0.613 & 1 & 1 & 12 & 9 \\
\hline H6 & St-Bresson & 1500 & 06.2011 & 101 & 80.1 & 200 & 7.86 & 0.429 & 8 & 6 & 13 & 5 \\
\hline $\mathrm{H7}$ & St-Bresson & 1500 & 07.2011 & 66 & 82.3 & 168 & 10.6 & 0.429 & 2 & 3 & 19 & 25 \\
\hline $\mathrm{H} 8$ & Aulas & $4000^{\mathrm{a}}$ & 2011 & 32.8 & 59.4 & 36.4 & 1.38 & $<\mathrm{dl}$ & $<\mathrm{dl}$ & 1 & 12 & 6 \\
\hline H9 & Majencoule & $7500^{\mathrm{b}}$ & 2011 & 145 & 62.8 & 206 & 12.8 & $<\mathrm{dl}$ & 1 & 1 & 3 & 14 \\
\hline RJ & les Avinières & 250 & 05.2011 & 33.8 & 61.7 & 123 & 0.304 & 0.906 & 5 & 7 & $<\mathrm{dl}$ & 168 \\
\hline $\begin{array}{l}\text { W } \\
\text { Unit }\end{array}$ & les Avinières & 250 & 05.2011 & $\begin{array}{l}167 \\
\mathrm{mg} \mathrm{kg}^{-} 1\end{array}$ & $\begin{array}{l}78.8 \\
\mathrm{mg} \mathrm{kg}^{-1}\end{array}$ & $\begin{array}{l}305 \\
\mathrm{mg} \mathrm{kg}^{-1}\end{array}$ & $\begin{array}{l}16.1 \\
\mathrm{mg} \mathrm{kg}^{-1}\end{array}$ & $\begin{array}{l}1.520 \\
\mathrm{mg} \mathrm{kg}^{-1}\end{array}$ & $\begin{array}{l}12 \\
\mu \mathrm{g} \mathrm{kg}^{-1}\end{array}$ & $\begin{array}{l}6 \\
\mu \mathrm{g} \mathrm{kg}^{-1}\end{array}$ & $\begin{array}{l}13 \\
\mu \mathrm{g} \mathrm{kg}\end{array}$ & $\begin{array}{l}<\mathrm{dl} \\
\mu \mathrm{g} \mathrm{kg}^{-1}\end{array}$ \\
\hline
\end{tabular}

$<\mathrm{dl}=$ value below detection limit

Distance from the closest mine, which is les Avinières for samples collected in Saint-Laurent-le-Minier and Font-Bouillens for samples collected in Saint-Bresson

a Distance from the mine located in Bez-et-Esparron.

$\mathrm{b}$ Distance from the les Jumeaux mine in Sumène.

(iii) $4 \mathrm{ml} \mathrm{HNO}_{3}: \mathrm{HCl}(1: 3)$. In each step, the resulting solution was heated at $100{ }^{\circ} \mathrm{C}$ until dry. Dry residues obtained after step (iv) were solubilised in $\mathrm{HNO}_{3}(2.5 \% \mathrm{v}$ :v) for analysis.

\section{Results and discussion}

\subsection{Soil TE content}

In a risk-based approach, French authorities issued guideline values for contaminated land management as stated in Table 1. Fixed Impact Values (FIVs), based on toxicity studies, consider the chronic risks to public health related to the actual land use: 'sensitive use' values were selected here due to the occurrence of human activities (housing, beekeeping). These values were defined to be used in a specific scoring framework, but may also provide information on the level of concern for a specific site (Carlon, 2007).

Measurements of the TE levels in soils are shown in Table 2. S1 and S2 taken from the les Avinières mine spoils and tailing ponds show the highest TE content, with values for $\mathrm{Zn}, \mathrm{As}, \mathrm{Cd}, \mathrm{Tl}$ and $\mathrm{Pb}$ largely above the FIVs. Soil from the Les Malines tailing ponds (S3) was very similar, except for its lower Tl content. Our measurements confirm that mining waste from the area should be considered highly contaminated. The other soils were all below the FIVs for $\mathrm{Zn}$ and $\mathrm{Cd}$ meaning that the $\mathrm{Zn}$ or Cd contents of samples S4 through to $\mathrm{S} 8$ should not be considered as potential threats to public health. Values for As, on the other hand, all exceed FIVs with an average 3.4-fold FIV for As. In this case, the potential toxicity and high concentrations of As should be taken seriously. $\mathrm{Tl}$ and $\mathrm{Pb}$ are more contrasted with a few values above the FIVs. However, there is a clear trend of a decrease in $\mathrm{Tl}$ and $\mathrm{Pb}$ concentrations
(Table 2) as the distance from the mines increased. Such a phenomenon is very likely to be related to dust transport by winds, a phenomenon previously reported for other historical mines (Sondergaard, Asmund, Johansen, \& Elberling, 2010).

One case of $\mathrm{Pb}$ early stage poisoning was reported in the area. It highlights the crucial need for further investigation in contaminant linkages. Water and wind erosion may result in widespread TE contamination with potential impacts on human health, activities and livelihoods (Conesa \& Schulin, 2010). Precautionary measures such as restrictions on the use of local wells for water supplies, and on the trade of locally produced vegetables are currently enforced. To our knowledge, the possibility of safe beekeeping in such a context was never considered.

\subsection{TE content of honey}

Ca, Mg and P with average levels ( \pm standard deviation) at $175 \pm 74.1,97.7 \pm 44.9$ and $72.4 \pm 20.6 \mathrm{mg} . \mathrm{kg}^{-1}$ are the main cations present in honey (Table 3 ). $\mathrm{Mn}$ and $\mathrm{Zn}$ are next, with average levels of $7.57 \pm 3.69$, and $0.571 \pm 0.440 \mathrm{mg} \cdot \mathrm{kg}^{-1}$, respectively, which were consistent with references herein. These elements are known for their physiological role and their presence in honey is of lesser concern.

A higher $\mathrm{Zn}$ content of statistical significance (Wilcoxon test, $z=-2.460, P=0.0139$ ) could be measured in honey samples $\mathrm{H} 1$ and H3-5 collected in the vicinity of mine dumps $(<250 \mathrm{~m})$ compared to H2, H6-9 collected further away $(>1500 \mathrm{~m})$. However all honey from the region ( $\mathrm{H} 8$ and $\mathrm{H} 9$ in particular) showed rather low $\mathrm{Zn}$ contents compared to the literature (Table 4). Floral composition was previously emphasised as a possible factor (Bogdanov et al., 2007) and the use of galvanised containers was reported as 
Table 4

Maximum TE levels previously reported in honey (mg.kg-1 fresh weight)

\begin{tabular}{|c|c|c|c|c|c|}
\hline Element & Max & Source & Element & Max & Source \\
\hline $\mathrm{Mg}$ & 373 & Pohl et al. (2009) & $\mathrm{Cu}$ & 34.6 & Pohl et al. (2009) \\
\hline $\mathrm{Al}$ & 132 & Pohl et al. (2009) & $\mathrm{Zn}$ & 113 & Pohl et al. (2009) \\
\hline$P$ & 398 & Devillers et al. (2002) & As & 1.93 & Terrab et al. (2005) \\
\hline $\mathrm{Ca}$ & 900 & Pohl et al. (2009) & Se & 0.09 & Terrab et al. (2005) \\
\hline $\mathrm{Cr}$ & 4.48 & Gonzalez-Paramas et al. (2000) & $\mathrm{Cd}$ & 5.78 & Pohl et al. (2009) \\
\hline Mn & 82 & (Stankovska, Stafilov, \& Sajn, 2008) & $\mathrm{Ba}$ & 2.63 & Pisani et al. (2008) \\
\hline Co & 2.46 & Pohl et al. (2009) & $\mathrm{Hg}$ & 1.35 & Pohl et al. (2009) \\
\hline $\mathrm{Ni}$ & 13 & Pohl et al. (2009) & $\mathrm{Pb}$ & 8.22 & Pohl et al. (2009) \\
\hline
\end{tabular}

a major source of Zn (Gonzalez-Paramas et al., 2000): such containers were not used in this case. Thus historical mining appears to have little influence on the $\mathrm{Zn}$ content of honey, an observation consistent with those by Bogdanov et al. (2007) or Lambert, et al. (2012).

The presence of other TE could be related to historical mining, namely $\mathrm{Pb}$ (mean $23-\min 3-\max 101 \mu \mathrm{g} \cdot \mathrm{kg}^{-1}$ ), Tl (mean $12-\min 1-\max 37 \mu \mathrm{gg}^{-1}$ ), Cd (mean $6-\min 1-\max$ $22 \mu \mathrm{g} \mathrm{kg}^{-1}$ ) and As (mean $2-\min 0-\max 8 \mu \mathrm{g} \mathrm{kg}^{-1}$ ). H8 and $\mathrm{H} 9$, which reflect background TE levels in honey from the region, actually show the lowest As and Cd levels, but an exception occurs for $\mathrm{Tl}$, with a high $\mathrm{Tl}$ level in H8. However, H3 harvested in the vicinity of the les Avinières mine dumps, shows the highest $\mathrm{Pb}$ $\left(101 \mu \mathrm{gg}^{-1}\right)$, Tl $\left(37 \mu \mathrm{g} \mathrm{kg}^{-1}\right)$ and $\mathrm{Cd}\left(22 \mu \mathrm{g} \mathrm{kg}^{-1}\right)$ levels, which correlates with our data in soil. However statistical analysis cannot relate TE levels to the presence or absence of historical mines. No significant differences in $\mathrm{Pb}, \mathrm{Tl}, \mathrm{Cd}$ and As levels could be highlighted using distance to mine as an explanatory variable (Wilcoxon test $P>0.05$ ). Besides, $\mathrm{Pb}, \mathrm{Cd}$ and As levels observed here are all below the highest values previously observed in honey (Table 4), and within the concentration ranges previously described.

Our measurements appear to confirm the views expressed by Bogdanov et al. (2007). Apiary products TE content is not directly related to the mineral content of the foraging area, and cannot provide quantitative information on environmental TE levels. As a result, honey production in a historical mining area also appears to be safe.

\subsection{TE content of royal jelly and beeswax}

Measurements on other apiary products, including royal jelly (RJ) and bees wax (W) were also performed (Table 3). The most abundant elements in royal jelly are those necessary for larvae development: $\mathrm{Ca}, \mathrm{P}, \mathrm{Mg}, \mathrm{Zn}$ and $\mathrm{Mn}$, which is consistent with previous studies (Stocker, Schramel, Kettrup, \& Bengsch, 2005). Leita, Muhlbachova, Cesco, Barbattini, \& Mondini (1996) highlighted higher $\mathrm{Cd}, \mathrm{Pb}$ and $\mathrm{Zn}$ content in royal jelly compared to the corresponding honey, which is not consistent with homeostasis observations by Stocker et al. (2005). In our case, the TE levels were comparable (H3, RJ).

Regarding elements that could be related to historical mining $(\mathrm{Zn}, \mathrm{Pb}, \mathrm{Cd}, \mathrm{Tl})$, concentrations in royal jelly are of the same order of magnitude as those previously reported outside mining districts (Bogdanov, 2006), and once again no impacts of mining could be inferred from statistical analysis of our measurements. The same trend was observed for beeswax, which had a low $\mathrm{Pb}, \mathrm{Cd}$ and $\mathrm{Tl}$ content. The low mineral content of beeswax should be noticed and detract from using it for TE monitoring.

\subsection{Potential health hazards resulting from honey consumption}

\subsubsection{Defining acceptable TE levels in honey}

The issue of potential health hazards related to the TE contamination of honey is usually left aside, possibly because of a lack of
Table 5

Maximum and minimum TE levels from regulation EC 1881/2006.

\begin{tabular}{lll}
\hline & $\mathrm{Cd}$ & $\mathrm{Pb}$ \\
\hline Max & $1 \mathrm{mg} \mathrm{kg}^{-1}$ & $1.5 \mathrm{mg} \mathrm{kg}^{-1}$ \\
Product & Bivalve molluscs & Bivalve molluscs \\
Min & $50 \mu \mathrm{g} \mathrm{kg}^{-1}$ & $2050 \mu \mathrm{kg}^{-1}$ \\
Product & Meat & Milk \\
\hline
\end{tabular}

legislation to define acceptable TE levels in honey and other apiary products (Devillers et al., 2002). It is stated by the Codex Alimentarius, that 'honey shall be free from heavy metals in amounts, which may represent a hazard to human health' (Codex Alimentarius., 2001). Yet these hazardous levels are not defined, and in the European Union for example, regulation EC $1881 / 2006$, which set the maximum levels for certain contaminants in foodstuffs does not address apiary products. Nonetheless, levels measured here for $\mathrm{Pb}$ and $\mathrm{Cd}$ in honey are all below the maximum levels stated by regulation EC 1881/2006 (Table 5).

\subsubsection{Bioavailability and consumption trends}

Although TE bioavailability from honey is high (Pohl, Stecka, Greda, \& Jamroz, 2012) consumption trends are determinant to assess the risks. For our sample with the highest TE content (H3 with $0.101 \mu \mathrm{g} \mathrm{g}^{-1} \mathrm{~Pb}$ and $0.022 \mu \mathrm{g} \mathrm{g}^{-1} \mathrm{Cd}$ ), a $20 \mathrm{~g}$ daily honey consumption for an average $65 \mathrm{~kg}$ person turns into a weekly intake of $0.218 \mu \mathrm{g} \mathrm{Pb}$ per $\mathrm{kg}$ body-weight and a monthly intake of $0.203 \mu \mathrm{g}$ Cd per $\mathrm{kg}$ body-weight. These intakes only represent about $0.9 \%$ of the Provisional Tolerable Weekly Intake (PTWI) for $\mathrm{Pb}$ and $0.8 \%$ of the Provisional Tolerable Monthly Intake (PTMI) for Cd (fixed by the World Health Organisation, namely $25 \mu \mathrm{g} \mathrm{Pb}$ per $\mathrm{kg}$ body-weight per week and $25 \mu \mathrm{g} \mathrm{Cd}$ per $\mathrm{kg}$ body-weight per month) (Food, 2010). Thus honey appears to be a minor component in TE intakes, a result previously emphasised in other studies (Pohl et al., 2012).

Nonetheless measurements in honey from les Malines showed Tl levels sometimes superior to that of $\mathrm{Pb}$ or $\mathrm{Cd}$. $\mathrm{Tl}$ is more toxic than $\mathrm{Pb} / \mathrm{Cd}$ and commonly appears in $\mathrm{Zn}$ sulphide ores. Thus, it is found at high concentrations in Zn-mine tailings (Peter \& Viraraghavan, 2005). Its presence in honey was not previously investigated. Additional data on the occurrence of this element in apiary products and other food products from the mining district could help assess the $\mathrm{Tl}$ content related to the presence of mine dumps and potential $\mathrm{Tl}$ impacts on health.

\section{Conclusion}

According to our results, in an environment heavily affected by historical mining, where soils are notoriously contaminated with $\mathrm{TE}$, apiary products remain of good quality with regards to two aspects: (i) the levels of TE measured were consistent with those usually found in uncontaminated areas, as shown from literature datasets (ii) according to WHO guidelines, the consumption of honey appears to be safe: a simple calculation for $\mathrm{Pb}$ and $\mathrm{Cd}$ taking into 
account the usually low honey consumption and its low mineral content, clearly show that it only introduces a very small fraction of these toxic elements into the diet. Consumption of other apiary products such as royal-jelly is very likely to be even lower, representing a very minor part of dietary minerals intakes. This could explain why reference levels for noxious TE in honey have so far not been set.

It also appears from our study, that apiary products should not be used for TE biomonitoring. In the case of historical mining, no clear contaminant linkage appear from mining waste to apiary products. The possible remediation options for historical mines are often subject to much discussion, although potential public exposure and impacts have not always been thoroughly investigated. In the case of Les Malines, our measurements showed that beekeeping could be safely performed and should not be restricted. It could maintain livelihoods as chestnut honey from the region is highly regarded for its unique taste. However, the case of other less studied TE, such as $\mathrm{Tl}$, deserves further investigation.

\section{Acknowledgements}

The authors gratefully acknowledge the CNRS, the ANR ECOTECH (11ECOT01101), the FEDER and ADEME for financial support. Particular thanks go to the Ecole Polytechnique - Paris Tech for a PhD studentship. We would also like to thank Remi Freydier (Plateforme AETE - Hydrosciences, Montpellier - France) for ICPMS analyses and Raphaelle Leclerc (CEFE UMR-5175 platform of chemical analyses - LabEx CeMEB - Mediterranean Center For Environment and Biodiversity) for guidance in sample treatment. Finally, we would like to thank Mr. Daniel Favas, a beekeeper from Saint-Laurent-le-Minier, France and member of the local honeybees health preservation group (GDSA, Gard) for his active help in supplying samples.

\section{References}

Bilandzic, N., Dokic, M., Sedak, M., Kolanovic, B. S., Varenina, I., Koncurat, A., et al (2011). Determination of trace elements in Croatian floral honey originating from different regions. Food Chemistry, 128(4), 1160-1164.

Bogdanov, S. (2006). Contaminants of bee products. Apidologie, 37(1), 1-18.

Bogdanov, S., Haldimann, M., Luginbuhl, W., \& Gallmann, P. (2007). Minerals in honey: environmental geographical and botanical aspects. Journal of Apicultural Research, 46(4), 269-275.

BRGM. (2012). Inventaire historique de sites industriels et activités de service. In).

Carlon, C. (2007). Derivation of soil screening values in Europe. A review and evaluation of national procedures towards harmonisation. In, (pp. 306): European Commission, Joint Research Centre, Ispra.

Codex Alimentarius. (2001). Standard For Honey (CODEX STAN 12-1981).

Conesa, H. M., \& Schulin, R. (2010). The Cartagena - La Union mining district (SE spain): A review of environmental problems and emerging phytoremediation solutions after fifteen years research. Journal of Environmental Monitoring, 12(6) 1225-1233.
Devillers, J., Dore, J. C., Marenco, M., Poirier-Duchene, F., Galand, N., \& Viel, C. (2002). Chemometrical analysis of 18 metallic and nonmetallic elements found in honeys sold in France. Journal of Agricultural and Food Chemistry, 50(21), 5998-6007.

Escarre, J., Lefebvre, C., Raboyeau, S., Dossantos, A., Gruber, W., Marel, J. C. C., et al (2011). Heavy metal concentration survey in soils and plants of the les malines mining district (Southern France): Implications for soil restoration. Water Air and Soil Pollution, 216(1-4), 485-504.

Food and Agriculture Organization of the United Nations. (2010). Joint FAO/WHO Expert Committee on Food Additives - 73rd meeting. In): Food and Agriculture Organization of the United Nations.

Gondard, H., Romane, F., Grandjanny, M., Li, J. Q., \& Aronson, J. (2001). Plant species diversity changes in abandoned chestnut (Castanea sativa) groves in southern France. Biodiversity and Conservation, 10(2), 189-207.

Gonzalez-Paramas, A. M., Gomez-Barez, J. A., Garcia-Villanova, R. J., Rivas-Pala, T., Ardanuy-Albajar, R. \& Sanchez-Sanchez, J. (2000). Geographical discrimination of honeys by using mineral composition and common chemical quality parameters. Journal of the Science of Food and Agriculture, 80(1), 157-165.

Grison, C., Escarre, J., Berthomme, M.-L., Couhet-Guichot, J., Grison, C., \& Hosy, F. (2010). Thlaspi caerulescens, an indicator of soil pollution? Actualite Chimique(340).

Hernandez, O. M., Fraga, J. M. G., Jimenez, A. I., Jimenez, F., \& Arias, J. J. (2005). Characterization of honey from the Canary Islands: Determination of the mineral content by atomic absorption spectrophotometry. Food Chemistry, 93(3), 449-458.

Lambert, O., Piroux, M., Puyo, S., Thorin, C., Larhantec, M., Delbac, F., et al. (2012). Bees, honey and pollen as sentinels for lead environmental contamination. Environmental Pollution, 170, 254-259.

Leguen, M., Orgeval, J. J., \& Lancelot, J. (1991). Lead isotope behavior in a polyphased $\mathrm{Pb}-\mathrm{Zn}$ ore deposit - Les Malines (Cévennes, France). Mineralium Deposita, 26(3).

Mihaly Cozmuta, A., Bretan, L., Mihaly Cozmuta, L., Nicula, C., \& Peter, A. (2012). Lead traceability along soil-melliferous flora-bee family-apiary products chain. Journal of environmental monitoring: JEM, 14(6), 1622-1630.

Monna, F., Camizuli, E., Revelli, P., Biville, C., Thomas, C., Losno, R., et al. (2011). Wild Brown Trout Affected by Historical Mining in the Cevennes National Park France. Environmental Science E Technology, 45(16), 6823-6830.

Peter, A. L. J., \& Viraraghavan, T. (2005). Thallium: A review of public health and environmental concerns. Environment International, 31(4), 493-501.

Pisani, A., Protano, G., \& Riccobono, F. (2008). Minor and trace elements in different honey types produced in Siena County (Italy). Food Chemistry, 107(4), 1553-1560.

Pohl, P., Sergiel, I., \& Stecka, H. (2009). Determination and Fractionation of Metals in Honey. Critical Reviews in Analytical Chemistry, 39(4), 276-288.

Pohl, P., Stecka, H., Greda, K., \& Jamroz, P. (2012). Bioaccessibility of Ca, Cu, Fe, Mg, $\mathrm{Mn}$ and $\mathrm{Zn}$ from commercial bee honeys. Food Chemistry, 134(1), 392-396.

Sondergaard, J., Asmund, G., Johansen, P., \& Elberling, B. (2010). Pb isotopes as tracers of mining-related $\mathrm{Pb}$ in lichens, seaweed and mussels near a former $\mathrm{Pb}$ Zn mine in West Greenland. Environmental Pollution, 158(5), 1319-1326.

Stankovska, E., Stafilov, T., \& Sajn, R. (2008). Monitoring of trace elements in honey from the Republic of Macedonia by atomic absorption spectrometry. Environmental Monitoring and Assessment, 142(1-3), 117-126.

Stocker, A., Schramel, P., Kettrup, A., \& Bengsch, E. (2005). Trace and mineral elements in royal jelly and homeostatic effects. Journal of Trace Elements in Medicine and Biology, 19(2-3), 183-189.

Terrab, A., Gonzalez, A. G., Diez, M. J., \& Heredia, F. J. (2003). Mineral content and electrical conductivity of the honeys produced in Northwest Morocco and their contribution to the characterisation of unifloral honeys. Journal of the Science of Food and Agriculture, 83(7), 637-643.

Terrab, A., Recamales, A. F., Gonzalez-Miret, M. L., \& Heredia, F. J. (2005). Contribution to the study of avocado honeys by their mineral contents using inductively coupled plasma optical emission spectrometry. Food Chemistry, 92(2), 305-309.

Tuzen, M., Silici, S., Mendil, D., \& Soylak, M. (2007). Trace element levels in honeys from different regions of Turkey. Food Chemistry, 103(2), 325-330. 